\title{
Property, Legitimacy, Ideology: A Reality Check
}

\author{
Enzo Rossi and Carlo Argenton
}

[Penultimate version. Forthcoming, The Journal of Politics, 2020]1

\begin{abstract}
Drawing on empirical evidence from history and anthropology, we aim to demonstrate that there is room for genealogical ideology critique within normative political theory. The test case is some libertarians' use of folk notions of private property rights in defence of the legitimacy of capitalist states. Our genealogy of the notion of private property shows that asking whether a capitalist state can emerge without violations of selfownership cannot help settling the question of its legitimacy, because the notion of private property presupposed by that question is a product of the entity it is supposed to help legitimise: the state. We anchor our genealogical critique in recent work on ideology in epistemology and philosophy of language, and in current debates on the methodology of political theory. But, unlike more traditional approaches that aim to debunk whole concepts or even belief systems, we propose a more targeted, argument-specific form of ideology critique.
\end{abstract}

\section{Introduction}

In his characteristically expressive review of Anarchy, State and Utopia, Brian Barry compares Nozick's position to

...the prejudices of the average owner of a filling station in a small town in the Midwest who enjoys grousing about paying taxes and having to contribute to 'welfare scroungers' and who regards as wicked any attempts to interfere with contracts in the interests, for example, of equal opportunity or anti-discrimination (1975: 331).

That is a harsh way of putting a point, yet some libertarians may welcome it, insofar as it exemplifies part of the intuitive appeal of their position: we have property rights regardless of the political system we live under. In this paper we contest the use of that folk view in arguments about the legitimacy of state power. In so doing we aim to offer an argument against some forms of libertarianism and, more importantly, the proof of concept of a new form of genealogical ideology critique.

1 This paper's long gestation is intertwined with the illness and premature death of one of its authors, Carlo Argenton, and it is dedicated to his memory. Enzo Rossi should take responsibility for most of the text as it now reads, but the ideas stem from conversations between the authors dating as far back as 2014, and some joint writing in 2015. The paper benefitted from being presented at the Dubrovnik Inter-University Centre, the LSE, SciencesPo, the University of Amsterdam, Sussex University, and Tulane University. Will Bosworth, Ed Hall, Rob Jubb, Naomi Goulder, Paul Sagar, Eric Schliesser, Nic Southwood, Matt Sleat, and Nicholas Vrousalis commented perceptively on various drafts. The Journal of Politics' political theory editors, Lisa Ellis and Jacob T. Levy, provided excellent feedback and guidance, as did their anonymous referees. Enzo Rossi's research was carried out within by his Dutch National Science Organisation 'Vidi' project 'Legitimacy Beyond Consent' (grant n. 016.164.351). 
Some argue that (some) libertarian moral assumptions are untenable, or that libertarian conclusions don't follow from them. Thomas Nagel famously described Nozick's position as 'libertarianism without foundations' (1974)—a structural critique focused on the circularity between assumptions and conclusions. We put forward a more radical kind of critique: we try to show an epistemic flaw in Nozick's attempt to justify a socio-political system through a normative commitment that is itself a product of that system. Our contention is that some of Nozick's assumptions, while perhaps tenable in their own right, should not feature in the sorts of arguments he and others want to deploy them in. We use empirical evidence from history and anthropology to show that folk notions of private property-down to and including selfownership-are statist in an unacknowledged way, which disqualifies them from featuring in arguments about state legitimacy. With few important exceptions (Bertram 2014, Widerquist and McCall 2015, 2017), the main empirical claim we rely on is usually ignored by contemporary political philosophers, but relatively uncontroversial among the relevant specialists: folk commitments to the political centrality of private property are a product of the agency of states.

Our critique has two substantive targets and a methodological upshot: (i) academic libertarianism that relies on folk notions of private property and, perhaps more importantly, (ii) public political discourse that appropriates such academic arguments in defence of a capitalist socio-political system. The latter is the 'everyday libertarianism' Liam Murphy and Thomas Nagel (2002) attack by arguing on conceptual and moral grounds that property rights are conventional. Ours is not a conceptual or moral argument, but an empirically-informed genealogical critique of some aspects of capitalist ideology. So the methodological upshot of our argument is that (iii) genealogical considerations can have purchase in normative political theory: a look at salient facts reveals the inadequacies of the abstractions in certain hypothetical arguments, and of the excessive reliance on 'common sense' or 'intuitive' judgments found in certain styles of normative political theory-parts of Nozick's argument being just examples of political philosophers' tendency to rely on such judgments.

To be sure, the general appeal of liberal rights is left largely untouched by our argument. The argument suggests, however, that it is prudent to investigate the genealogy of concepts featured in arguments with high political stakes, especially when those arguments can be used to defend the most powerful in society, since ideology tends to skew in their favour. But our strategy differs from broadly Gramscian or Foucauldian approaches: we do not aim to debunk all talk of private property, let alone the whole ideological background of such talk, but just the use of folk beliefs about private property in one specific kind of argument. We maintain that such targeted genealogical debunking is best placed to engage productively with contemporary political philosophy. Our approach is also an advance relative to standard Marxian 
interest-based ideology critiques, as it draws only on empirical evidence and the epistemic properties of beliefs, not on more normatively contestable attributions of interests to social classes. And we do not purport to offer our critique from an ideologically neutral standpoint; we merely argue that some beliefs are ideological in a pejorative sense of the term, which we expound. To cement this point we draw on recent work on genealogy and ideology in philosophy and language and epistemology, as well as on current debates on the methodology of political philosophy.

The basic libertarian argument we discuss can be summarised as follows:

P1: Any socio-political system that emerges and reproduces itself without violations of self-ownership is legitimate.

P2: A capitalist system can emerge and reproduce itself without violations of self-ownership.

C: A capitalist system can be legitimate.

Note the 'can' in the second premise. 2 That argument is hypothetical. Factual considerations about how capitalism came about in the actual world cannot disprove the second premise. However - and this is the crux of our argument — the actual history of capitalism and the related genealogy of our notion of selfownership lead us to conclude that asking whether a capitalist state can emerge without violations of self-ownership cannot help settling questions of state legitimacy, because the notion of private property presupposed by that question is a product of the private property-protecting state it is supposed to legitimise (and that sort of state, in turn, is a precondition for the development of a capitalist socio-political system). Put another way, facts cannot prove Nozick's hypothetical story false; but they can show that the question Nozick asks presupposes the falsity of the real history of property rights and the state. A politically central notion of private property could have emerged independently of the state; but the fact that it didn't disqualifies it from featuring as a 'common sense' assumption in arguments about state legitimacy in the actual world.

Now, to partly anticipate an objection, let us grant that the idea of a moral right to private property is, in principle, unconnected to the history of how one came to believe in such a right, or how the corresponding legal rights emerged. There could be moral rights even if nobody believed in them, or if anyone who believed in them had been brainwashed by someone who benefits from that beliefthis is why debunking ideology critiques are often accused of committing the genetic fallacy. The question remains: why rest arguments on common sense beliefs in moral rights to private property if those beliefs have been acquired in an epistemically suspect way? That question can be ignored by natural law theorists, Platonists of various stripes, and so on. Our argument does not touch such and other philosophical defences of property rights,

2 Some would argue that only capitalism can emerge and reproduce itself without violations of self-ownership rights. By discussing the less controversial version of the argument we cast a wider net. 
such as personhood-based accounts (Gradin 1982), or the consequentialist or conventionalist accounts prevalent among contemporary libertarians (Brennan, van der Vossen \& Schmidtz 2017). It touches arguments that relies on the common sense appeal of property rights in theories of state legitimacy.3 Still, even with this domain restriction to explicitly or implicitly antifoundationalist arguments, the question is not rhetorical, which is why we shall provide an account of ideology in support of our preferred answer.

The paper's structure is this. We set the stage with an exposition of the view we critique, with a focus on Nozick's invisible-hand theory of state legitimacy. We then look at empirical evidence on the real-world counterpart of the invisible hand story. In the subsequent section we provide an account of ideology that sets out the desiderata for an effective genealogical debunking, which we carry out in the penultimate section. Building on that, in the conclusion we discuss the methodological pitfalls in genealogically unexamined political moralism.

\section{From self-ownership to the capitalist state}

The variant of libertarianism we engage is a thesis about selfownership and the state. 4 It says that the only type of state compatible with self-ownership is a minimal state, tasked solely with protecting the private property holdings of its citizens (derived from self-ownership plus a theory of appropriation of external resources), and consequently upholding a capitalist system of exchange. So the libertarianism we discuss is not just any defence of a market-based or market-centred socio-political system. It has similar conclusions to neoliberalism, or market liberalism, or classical liberalism, but it is not the same view insofar as it has a distinctive justificatory route to these conclusions, characterised by a focus on individuals' entitlements.

Another way to pick out the libertarianism that is the target of our critique is indeed to distinguish between desert- and entitlement-based justifications of capitalism (Olsaretti 2004: 2-5): one may be entitled to an inheritance without thereby deserving it, and vice-versa. Desert-based justifications appeal to a substantive principle of distributive justice: just distributions conform to a pattern determined by a conception of desert (e.g. that nobody deserves more than anyone else, or less than they need to survive, say). Such patterns are irrelevant for the purposes of entitlementbased justifications, which assess political arrangements solely on the basis of whether they came about without violating the rights of those affected.

Robert Nozick's libertarianism (1974) is the archetypal entitlement theory. Like most libertarians, Nozick takes anarchism seriously. He doesn't just offer arguments in favour of his preferred

3 As Nozick puts it, his book "does not present a precise theory of the moral basis of individual rights" (1974: xiv).

4 So we set aside accounts of libertarianism not grounded in the inviolability of individual rights. 
political system. He nests those arguments within a theory of why we should have a state rather than not. He then constructs a theory of justice in close connection to this theory of legitimacy. In fact Nozick's political theory, i.e. his theory of legitimacy and justice, is in three parts: (i) an entitlement-based argument for the moral permissibility of a minimal state (as opposed to anarchy), (ii) an argument against pattern-based theories of distributive justice, and (iii) an argument for the desirability of the minimal state. Both (i) and (iii) are necessary to meet the anarchist's challenge, as the anarchist can claim that the state is morally impermissible, and/or that it is undesirable. Here we will focus primarily on (i), and remain neutral on the extent to which (ii) and (iii) depend on it. We will look closely at one of the two pillars of Nozick's theory of legitimacy, namely the argument for the state's moral permissibility, in which Nozick asks us to imagine a state of nature-type scenario. The key to the moral permissibility of the state is not to be found in consent, but in an invisible-hand story showing that a state could arise without any rights-violations. The story aims to show that the state would be the preferred solution to a range of relevant problems. What is more, such a state could emerge voluntarily but unintentionally, or at any rate not by design.

For our purposes a simplified outline of Nozick's story will suffice, as we won't be taking issue with its substance, which has been widely criticised (Bader 2010: 81-85), but rather with the method. The story begins in an anarchic situation, with individuals in charge of the enforcement of their own moral rights. Nozick doesn't paint an overly pessimistic, Hobbesian picture of this situation: he imagines a high level of compliance with his rightsbased moral order. Nonetheless, to safeguard their rights more effectively people will form mutual-protection associations tasked with enforcing members' rights. To maximise efficiency those associations will gradually evolve into professional organisations. One of those agencies will become dominant and then, Nozick argues, it will be able to claim a state-like monopoly of violence without violating anyone's rights (1974: 16-17). The minimal state is tasked only with enforcing citizens' negative rights, i.e. rights of non-interference with bodily integrity, movement, property transactions, and so on. This nightwatchman state, then, supports the development of a capitalist social system: there are no limits to the accumulation of rightfully acquired private property, few restrictions on freedom of contract, and redistribution is limited to the mere cost of enforcing negative rights.

Note that the invisible hand theory is about the justification of the state, not of (private) property. As we'll see in more detail below, Nozick's account of appropriation depends on his assumption that individuals are self-owners, which in turn presupposes some notion of private property rights. Property rights can be divided in two sets: rights of self-ownership and of world-ownership. The former are assumed as the theory's starting point. The latter are the product of the former plus some theory of 
justice in acquisition, transfer, and rectification. 5 We return to the relationship between self-ownership and world-ownership below. For now it will be enough to note that self-ownership is a necessary but not sufficient condition for explaining private ownership of parts of the external world.

That sketch of Nozick's theory of legitimacy indicates how his story features many of the modes of social interaction-and, presumably, the underpinning normative commitments-familiar from life under a capitalist system. And he doesn't presuppose just their existence (they predate capitalism and states after all) but also their distinctly capitalist political pre-eminence relative to other features of social life. As we'll see in some detail, the point here is that Nozick's state of nature is decidedly oriented in the direction of the system Nozick intends to ground. By now we know better than to demand a blank slate-like original position. Still, there is a spectrum of more or less appropriate ways to front-load hypothetical scenarios with normative commitments. Is this particular hypothetical a good way to justify a capitalist social system? That partly depends on how the capitalist social system actually came about.

\section{Actually-existing capitalism}

How does Nozick's hypothetical state of nature compare to its counterparts in the actual world? Nozick himself thought the question mattered (1974: 293-294), though, as we'll see in the next section, for different reasons from ours. For now, suffice it to say that, even though Nozick's invisible hand story is a counterfactual, the question matters because it points to the sorts of assumptions that should and shouldn't feature in the antecedent of any conditional whose consequent is meant to have normative relevance in the actual world. Nozick's project of justifying capitalism as the possible historical product of voluntary cooperation between original acquisitors requires us to imagine pre-political individuals with a strong folk belief in the political salience of their private property entitlements. In this section we adduce empirical evidence for the claim that, in the actual world, that folk belief is largely a product of the state, due to two distinct but related historical developments. Crudely, the first one is the creation by the first states of an order in which individual private property is central and politically salient. The second one is the early modern state-backed rise of capitalism. In subsequent sections we show how those facts turns out to be a problem for Nozick. 6 But before approaching the evidence, let us introduce a working definition of the state, and two distinctions: between the market and capitalism, and between individual and collective private property.

${ }_{5}$ Cf. Bader 2010: 188, 190, who maintains that it is unproblematic to assume a need for private property in the external word, even though it's hard to explain exactly what gives rise to it.

6 Strictly speaking, either of those facts would suffice for our argument to go through. 
For our present purposes we can follow anthropologists and archaeologists and think of the state as the political entity continuous with the successors of early chiefdoms. Predynastic Egypt, the preclassic Maya, the Uruk period in the Middle East, Shang China, and the Harappan period in the Indus Valley are some of the most prominent examples. Most of their distinguishing features-hierarchical and codified authority structures, urbanisation, a bureaucracy, a measure of military control over their territory, and the raising of taxes - are still shared with modern states (Scott 2017, Wengrow 2010), though those are far more tentacular in their reach and far more internally coherent, to a degree approximating a qualitative rather than just quantitative change, especially as regards the "unity of authority" (Levy 2017: $5)$.

We can think of the market as the domain of voluntary exchange of goods. This definition allows for the compossibility of (some) market relations and a number of social and cultural systems. All that has to be present for market relations to emerge is the willingness to exchange a good for another. Thus defined market relations have been with us for such a long time that it would be difficult to speak of them as anything else but 'natural' to humanity, given the limits of autarchy. This does not mean that the act of exchanging always has the same meaning for the two parties involved, nor that self-interest is always the sole or primary driving force (Deagan and Cruxent 2002), nor that exchange is a dominant or even important organising principle of society (Granovetter 1985).

On the other hand, capitalism, at least as we know it-there could be roads not taken, as there certainly are other theoretical possibilities - is a system of productive relations in which the market and the state take specific, prominent roles. As our historical discussion below will explain, the system revolves around four key elements: (i) individual private property, (ii) wage labour as a means of subsistence and consumption for a large part of the population, (iii) the sanctioned aim of profit-maximisation on the part of the owners of capital, and (iv) state-enforcement of (i)-(iii). Whilst such a system can coexist and vary with a number of sociocultural backgrounds, their range is substantially narrower than that allowed by market relations (Hall \& Soskice 2001).

Element (i) is crucial here, and leads to our second distinction: individual private property (henceforth PP1), as opposed to collective private property (henceforth PP2). Private property is, fundamentally, a matter of socially sanctioned exclusion, as prominent conceptual accounts put it (Merrill 1998, Penner 1997):7 it is a matter of drawing boundaries around a certain resource or resource system and policing access to it (McKean and Ostrom 1995) - a variable practice best thought of as "a continuum from identification and association with things to social and political

7 Here we characterise property in formal terms, and remain neutral on the normative issues of the interests and values it may protect (Dagan 2003) or the function it may serve (Waldron 1988). 
possession to ownership enforced by the rule of written law" (Earle 2017: 3). Roughly, when communities engage in this form of exclusion or privatisation we have PP2; when individuals do it we have PP1. To be sure, this distinction ranges over standard anthropological and archaeological classifications, which normally envisage a more complex picture featuring commons, institutional property, and various versions of private property (Gilman 1998). In the introduction to an important two-volume collection on the anthropology property and inequality, in fact, we read: "When investigated ethnographically, all property regimes seem to be more or less ordered conglomerates of both private rights and communal rights" (Widlok 2005: 8). Our distinction is just meant to individuate the idealtyp of PP1, the form of private property that features in Nozick's argument. PP1 is present when the type of resources essential to the productive activities that sustain society — capital, if you will—can be held by individuals.

That development in turn reconfigures key aspects of a community's political arrangements. So we must begin to introduce the anthropological and historical evidence, which shows how PP1 should not be considered a politically neutral baseline, pace Nozick. If there is anything that emerges as such a baseline from the historical and anthropological record is a virtually unanimous understanding of property as PP2.8 Let us trace a schematic history of the evolution of property relations. Bearing in mind that the process is neither linear nor synchronic, the mainstream view among anthropologist is that, as an influential review article puts it, "social evolution can be characterized heuristically as having overlapping institutional scales of organization: the family level (bands), local groups (tribes), chiefdoms, and states. [...] Special forms of property can be associated with increasingly broad levels of integration." (Earle 2000: 45). Indeed, until about 12,000 years ago, all humans lived in hunter-gathering or foraging bands. A standard feature of band societies of this kind, and of hundreds of village and/or tribe-based societies as well, is a land tenure system based on some variation of PP2 (Lee and Daly 1999). Though moveable property tends to be held by individuals, land-the main productive resource-is held by a kinship-based collective, typically sustained by an ethos of reciprocity. Generally, the purpose of access to land and other key productive resources was sustenance, and sustenance required appropriation of some kind. What it did not require, however, was individual ownership in Lockean-Nozickian, PP1 sense of the term. The prevailing principle was that no individual (or, most commonly, family) could claim exclusive use of any piece of land, and no individual or family could be excluded from resources they needed to subsist (Widerquist \& McCall 2015). Usually this principle required some

8 So the PP1-PP2 distinction allows us to make our argument while remaining neutral on the controversy between conventionalist and natural right accounts of property (Bertram 2014): we do not need to take a position on whether property tout court is tied to innate abilities, since our focus is on the transition from one kind of property to another. 
form of use-rights, not exclusive individual ownership. If at all, exclusive ownership took the PP2 form, with the entire band as the original appropriator (Fried 1967: 201). With some partial exceptions in pastoralist societies (Porter 2012), the key consideration remained land use, not the exclusive individual ownership of property (Sahlins 1974: 92-93).

The first sedentary, village-based tribal societies also largely adhered to this pattern. This becomes especially clear once we abandon the now discredited view of a linear evolution from foraging to agriculture, wih the latter as the enabler or sedentism. As James Scott shows in a recent book summarising vast quantities of empirical research, sedentism predates agriculture (Scott 2017). So, even though Rousseau's old conjectural linkage between agriculture, sedentism and inequality doesn't quite stand up to empirical scrutiny, Scott shows convincingly that agriculture is indeed key to state formation and thus inequality, as we'll see shortly, after a brief discussion of the state's predecessor, the chiefdom.

Chiefdoms have been shown to represent the first phase of a process of PP1-like privatisation.9 Typically, land was removed from the commons and ownership transferred to groups or institutions. If one looks for PP1 one finds that "there is no evidence (...) that such land existed in most early civilizations" (Trigger 2003: 332). Nonetheless chiefs were individuals who were powerful enough-in a context of population pressure and thus increasing competition for scarce land resources-to appropriate for their clans land previously held in common (Earle 2017). Access to land became restricted, with small sections of the population now in a position to determine who had access to what, typically in connection with gendered and kin-defined hierarchies (Bouchard 2011, Gailey 1985).

The dynamics of appropriation in early states intensified this process:

Based on historical and archaeological evidence, complex societies rested on the development of property rights well before capitalism. [...] The emergence of the state was an outcome of social stratification in which the ruling institutions defended differential access to or ownership of strategic resources by military means [...] central power, whether comparatively strong or weak, arises from property rights (Earle 2000: 44).

That is to say, property rights are an instrumentum regni. A crucial aspect of the process was the need to use PP1 in part as a strategy to raise taxes: an influential study of seven cases across a wide variation in time and space (Aztec, Maya, Yoruba-Benin, Egypt, Mesopotamia, and Shang China) concludes that "the

\footnotetext{
9 However some Holocene complex foraging societies, which preceded chiefdoms, may represent a small exception to the PP2 norm by displaying a family-based variant of PP1 (Johnsen 1986). Yet even uncertainty about the origins of private property would be enough to cast doubt on the view we attack, since we argue that the view requires the falsity of the actual history of PP1.
} 
replacement of collectively owned land by increasing proportions of [...] privately owned land is correlated with compelling farmers and farm labourers to produce and surrender increasing amounts of surplus food" (Trigger 2003: 336). Another, related, common way in which private land originally spread can be traced to the decision on the part of these rulers to reward officials and others members of the elite for their services with exclusive titles to land (Trigger 2003: 147).10 The common element here can be brought into focus through Scott's theory of the agrarian origins of the early states: "the embryonic state arises by harnessing the late Neolithic grain and manpower module as a basis of control and appropriation." (2017: 116) With sedentism and various effective means for self-sufficiency in place, the emergent state elites had to find coercive ways to funnel their subjects' productive activities into the types of agriculture that produced an elite-appropriable surplus. So "each of the earliest states deployed its own unique mix of coerced labor" (ibid.: 152-3). We may then see the gradual rolling out of PP1 as a way to overcome this direct form of coercion and bring forth a more familiar (to us) situation: "Only much later, when the world was, as it were, fully occupied and the means of production privately owned or controlled by state elites, could the control of the means of production (land) alone suffice, without institutions of bondage, to call forth a surplus." (Ibid.: 153)

A valuable interpretive key of that process can be found in the idea of "state simplification", from Scott's earlier work on state formation (1998). According to Scott, the state-and the modern state even more so-is an institution that strives to make the population and territory it exerts control over as "legible" as possible, to manage it more effectively. Importantly, for Scott the state does not just 'read' its population and territory in a simplified manner, but also actively and coercively shapes these in the direction of greater simplicity and standardisation. The transition from the complexity of PP2 to the simplicity of PP1 can be read as such a state simplification. Through PP1 the state made property relations more legible, manageable, and most importantly taxable (ibid.) - a crucial element in the state-agriculture-PP1 nexus. This pattern is characteristic of all early states. Indeed we think Scott's insight about their agricultural roots is a useful buttress for the standard account of the link between property and the state, once we combine it with his theory of state simplification and legibility: "Tributary economies of both chiefdoms and precapitalist states require alienation of value to finance stratification and institutional elaboration. [...] elite ownership (and the corresponding ability to extract tribute from commoners) was basic to the emergence of social complexity." (Earle 2000: 44). Note the emphasis on taxation. And this is what Scott says about all early states and their dependence on cultivated grains: "The key to the nexus between grains and states lies, I believe, in the fact that only the cereal grains can serve as a basis for taxation: visible, divisible, assessable,

10 Comparable processes can be observed in shepherding societies as well (Farringdon 2005). 
storable, transportable, and 'rationable" (Scott 2017: 129). The early state's dependence on agriculture, then, requires PP1 as an instrument to make resources legible: "Land, happily for the tax collector, does not move. But as the Qin recognized private landholding, it conducted an elaborate cadastral survey connecting each piece of cropland with an owner/taxpayer." (ibid.: 146) In a nutshell, PP1 both drives state formation and is a tool of its entrenchment.

To be sure, the variants of PP1 implemented by early states do not have all of the features of modern capitalist property. Nonetheless, as we have seen, we can tie individual property titles to the early states, and that remains a necessary condition for the subsequent developments that will see the rise of European capitalism in connection with the modern state-the second historical development mentioned above. This story is both more familiar and more contested. The familiar part is that capitalism as a distinctive productive system comes into existence in England around the 18th century, and that, more recently still, European colonialism was the principal cause for the spread of this radical simplification of ownership titles and notions of property to the rest of the world, as most research indicates.11

Exactly how this came about is controversial. We will not take sides in those debates, but highlight historical developments so as to see how, under the modern state, the early states' relatively fragile reliance on PP1 was reinforced and became the entrenched system that sustains capitalism as we know it. So, for instance, legal-institutionalist scholars show how capitalism results from purposeful legal and political action on the part of the state (Deakin et al. 2016), exemplified most clearly by the state-driven financialisation of PP1 in the England of the early 18th Century, achieved mainly via the legal conceptualisation of land as collateral and debt as saleable property, which in turn enabled the development and explosive growth of the industrial and protoindustrial economy we typically associate with capitalism (Hodgson 2016). A more familiar yet compatible narrative and, importantly for our purposes, one that attributes an equally central role to the state, starts a little earlier. It looks at how land came to become something that could be used as debt collateral, and so centres on the long process of land tenure reforms in England from the 16th to the $19_{\text {th }}$ Century. The importance of the enclosure of the commons - the state's coercive turning of PP2 into PP1 - to the rise of capitalism is well-known: Georgian-era landowners used their influence on the state to appropriate common land and erode customary use-rights. In the process they deprived a large population of their means of subsistence, forcing them to seek employment in the nascent textile and other industries. Ellen Meiksins Wood (2002) enriches that standard narrative by extending it into the past and sharpening the picture of the role of the state. She shows that the enclosure movement couldn't have 
succeeded without the "distinctive political centralization of the English state" (ibid: 99), achieved already in the 16th Century. Furthermore, she shows how the Lockean-biblical ethos of land improvement - used to justify much of the enclosure movementprovided the basis for capitalist productivism, later to be sublimated in the industrial era: "the landlord who puts his land to productive use, who improves it, even if it is by means of someone else's labour, is being industrious ... The kind of appropriation that can be called 'productive' is distinctively capitalist." (ibid.: 112-3)

So, in a somewhat speculative way, we can say that our focus on the political centrality of PP1 as tool of state simplification and on its origin as property in land allows us to trace a long arç spanning from Scott's theory of the agrarian origin of the state to Meiksins Wood's account of the agrarian roots of capitalism.

Definitions of capitalism vary; yet all accept that the political centrality of PP1 is a necessary condition for its emergence. As Hume and Kant understood, property is not a relation between a subject and an object, but a social construct. A change in property relations is premised on a change in social relations. The state-in both its pre-modern and modern articulations-brought about such radical transformations in social relations, critical expressions of which were the implementation and subsequent entrenchment of the political salience of PP1.

\section{Ideology and political moralism}

How do the empirics we just discussed advance the argument outlined earlier? The working account of ideology we require to support our genealogical debunking of the role of PP1 in arguments about state legitimacy such as Nozick's has two main desiderata. According to the realist desideratum, ideology critique must eschew unexamined pre-political moral commitmentslapsing into political moralism, to use Williams' terminology-as they may turn out have the same status as the object of our critique. According to the debunking desideratum, it must steer clear of the 'genetic fallacy', namely the mistake of confusing the problematic causal history of a belief with the lack of independent arguments in its favour.

The realist desideratum matters insofar as the critic wants to distance herself methodologically from the object of critique. This is a standard move within the Marxian tradition of ideology critique, which is sceptical of morality-driven critiques of the status quo, insofar as "effective norms of right and justice (if correctly understood in their actual social function) are largely weapons of the oppressive class." (Wood 2004: 145). But, even though it is compatible with it, the desideratum does not require commitment to that general approach. Here we are criticising libertarians who help themselves to a folk moral belief in private property rights to support a controversial political position. Any critique of this move cannot itself rely on any such folk beliefs-at least not without subjecting them to the same critical standards, which would derail the exercise. So one may want to bracket Williams' own account of 
the underpinnings of the Critical Theory Principle: "an aspiration to the most basic sense of freedom, that of not being in the power of another" (2002: 231). It is at least not obvious that aspiration differs in relevant ways from, say, the aspiration to hold secure private property rights.12 The worry is not that Williams's appeal to freedom is vulnerable to challenge from other rights, but that it is as genealogically unexamined as Nozick's appeal to property rights.

To avoid that worry while retaining the causal element in the critical theory principle we propose to motivate it with epistemic rather than moral considerations, by (i) displacing the causal element from the process of belief acquisition tout-court to the origin of the meaning of the relevant concept, which in turn will help us (ii) explain in epistemic terms why some folk beliefs are problematically resistant to rational revision, and thus ideological in the pejorative sense.

Move (i) draws on a recent reformulation of the social constructionist critique of ideology by Sally Haslanger, which relies on the distinction between internalism and externalism in semantics. Crudely, the thought is that insofar as concepts such as 'private property' are embedded in social practices, their meaning "is determined not simply by intrinsic facts about us but at least in part by facts about our environment." (2012: 395).13 Regardless of speakers' apparent competence in deploying the concept in ordinary language, because of the ways in which dominant social forces shapes the common ground of meaning, the concept cannot be investigated simply by appeal to our intuitions (semantic internalism), but rather "will need to draw on empirical social/historical inquiry" (ibid: 396 - semantic externalism). Attention to the causal history of the concept will then provide a better understanding of how the concept works (ibid:: 132-137), as in the social realm there is often a difference between the 'manifest' and the 'operative' concept (ibid.: 387-390). One can be a competent user of the manifest concept without fully understanding the operative concept, which is why we can carry out empirically-informed ameliorative conceptual analysis, e.g. to determine "whether our gender and race vocabularies in fact track social kinds that are typically obscured by the manifest content of our everyday concepts" (ibid:: 224).

In the case of race, say, this is a way to account for its social construction, and so to open some avenues for critique. In the case of private property, the manifest concept of private property is one that sees this right as a constraint on state activity, and so as a

12 This point holds even if one-correctly_understands Williams' appeal to freedom as subject to a 'realism constraint' that makes it sensitive to context (Hall 2015: 4-6). Hall also suggests that this aspiration is a naturalized 'want' rather than a belief. For a rejection of this sort of move in relation to ideology critique see Stanley (2015: 187-189). Alternatively one may read the appeal to freedom as a necessary condition for the exercise of one's epistemic faculties (Aytac forthcoming), in which case our position would still be fairly close to Williams's.

13 As in the familiar naturalised investigation of the meaning of natural kinds such as 'water'. 
notion that can feature in accounts of state legitimacy. But our causal reconstruction of the notion of PP1 shows a different operative concept: PP1 is best thought of as one of the tools employed by the state to make the social world legible (in Scott's sense) and to give structure to its rule. The meaning of PP1, then, is best understood partly by considering the causal history of the concept and the role it plays in our social and political practices. The empirical component of our analysis provides an epistemic reason to divert our attention from the manifest to the operative concept of private property - the latter simply is a more accurate description of the concept's role in our practices.

In response to anyone wishing to defend the primacy of intuitions and 'common sense' understandings of socially relevant concepts (i.e. the manifest concept), we can buttress the genealogical critique with Jason Stanley's (2015) account of ideology as epistemically flawed, rational revision-resistant beliefmove (ii) above. The relevant belief here would be something along the lines of "Private property is a normative commitment whose appeal as a central political commitment is independent of the existence of states (and so can feature in the legitimation of states.)" In light of the empirical evidence we provided, there is reason to rationally revise that belief-to move away from the manifest concept and towards the operative one. Any residual surviving appeal of the manifest concept of PP1 as stateindependent would be, following Stanley, ideological in the pejorative sense: "The distinctive feature of ideological belief is that it is very difficult to rationally revise in light of counter evidence", because of its connection to social practices (ibid.: 184).14 There are social structures that inhibit revision of beliefs such as those tied to the concept of PP1 as a state-independent, central political constraint. Those structures are especially resilient when, as in the case at hand, the ideologically flawed version of the concept advances the interests of the most powerful in society, or what psychologists call "system-justifying ideologies" (Jost \& Hunyady 2005). That is to say, power inhibits our appreciation of evidencethe ideological flaw is an epistemic flaw.

So we have provided two jointly sufficient conditions for triggering the Critical Theory Principle: that an epistemically ameliorable politically charged concept features in the relevant argument, and that this concept is resistant to amelioration despite the empirical evidence. Note how the identification of the epistemic flaw rests on the plausibility of the causal account of the operative concept, 15 so the debunking desideratum is met. But no moral notions are invoked in the debunking process: the flaw is epistemic, so the realistic desideratum is met.

14 Here Stanley's account of ideologically flawed belief chimes with Haslanger's semantic externalism: “... while I theorize with a category of ideological belief ... this does not mean that I think that being ideological is an intrinsic property of mental states" (2015: 186).

15 We use a causal theory of reference rather than of knowledge so we can remain neutral on whether the folk beliefs at hand constitute knowledge. 


\section{Abstractions and reality}

We can now leverage our historical and genealogical observations and our account of ideology to mount an objection to entitlementbased defences of capitalism. The empirical evidence discussed above shows how what is often taken by libertarians to be the spontaneous expression of the free individual human will-i.e. PP1-based capitalism - turns out to be something of a radically different nature. Without the state, PP1 would not be what it is. But why does this matter for a hypothetical, normative theory such as Nozick's? Crudely, because the political salience of private property rights was established by the state's political power, and only later became part of a widely shared moral vocabulary. So, when justifying or seeking to limit the state's authority, libertarians cannot simply help themselves to folk beliefs about rights. Raymond Geuss' pithy observation applies here: "Ethics is usually dead politics: the hand of a victor in some past conflict reaching out to extend its grip to the present and the future" (2008: 42).

Let us begin by restating the basic argument we discuss:

P1: Any socio-political system that emerges and reproduces itself without violations of individual rights is legitimate.

P2: (Only) capitalism can emerge and reproduce itself without violations of individual rights.

C: (Only) capitalism can be legitimate.

We should now unpack it to see exactly what role private property (PP1) plays in it:

P1: People have private property rights over their bodies (self-ownership).

P2: Self-owners can legitimately acquire external private property.

P3: Private property enables legitimate market transactions (free market).

P4: (Only) a state no bigger than a minimal state can arise spontaneously and legitimately as a result of a process kick-started through market transactions. 16

C: Given a commitment to private property rights, (only) such a minimal state can be legitimate.

PP1 plays a role both within self-ownership and worldownership (i.e. acquisition of external property; we return to this distinction towards the end of this section). The common understanding of self-ownership requires PP1, so much so that sophisticated philosophical critiques are needed to cash out relationship to our own bodies in non-property terms (e.g. Pateman 2002), though our argument does not depend on those critiques. At any rate, the argument can be understood as a conditional: if there can be private property before the state, then a minimal state can emerge without coercion. Notice how, given its level of abstraction, the antecedent treats as equivalent two very

16 Here we can ignore the transition from Nozick 'ultra-minimal state' to the minimal state. 
different pictures of statelessness, or of the state of nature: situation $\mathrm{A}$, in which some or even a majority of people hold a normative commitment to PP1 amongst their many other commitments, and a situation $\mathrm{B}$, in which PP1 is a near-inviolable moral constraint on political action and so has to become the centrepiece of political order, as per Nozick's account of rights as 'side constraints'. We have seen that $\mathrm{A}$ is a fairly accurate description of the world before states. B, on the other hand, could be described as a situation that might obtain if today's capitalist states disappeared overnight. Now, while a spontaneous transition from $A$ to $B$ is strictly-speaking possible, the empirical evidence we presented in the previous section shows that it never occurred in actual history despite vast contextual differences. The widespread acceptance of the centrality of private property to political order postdates the state, and is a product of its agency, though not only of its agency. That does not make the argument unsound or invalid, but it does show that, in order to get the desired pro-capitalist conclusions, Nozick has to build equally pro-capitalist normative commitments into the premises. The argument is not as parsimonious as it purports to be.

But our charge is not simply one of circularity, for a libertarian might well reply that she is simply spelling out the implication of the appealing, intuitive normative commitment to private property rights. We aim to show that libertarians are not entitled to help themselves to 'common sense' intuitions and beliefs about private property rights for the purpose of justifying the state. Our objection-in its crudest form-is that libertarians cannot use the intuitive appeal of private property entitlements in their defence of the capitalist state, because the historical record shows that widespread belief in the central political relevance of those commitments is the causal product of the very coercive order the belief is meant to support. One could have formed that belief in some other way; but given the empirical evidence in support of the state as the proximate cause, the burden is on the libertarian to show that the belief is warranted by other considerations.

To be sure, a philosophically sophisticated freestanding defence of PP1 as a near-absolute side constraint could be found, just as our critique can be formulated despite the social pressures in support of the political centrality of PP1. But the point remains that the widespread, folk appeal of PP1 vaunted by libertarians is susceptible to genealogical debunking. In other words, to resist our argument libertarians would have to navigate some troubled philosophical waters that they often, and understandably, try to avoid-e.g. by starting out with the assumption that "people have rights" (Nozick 1974: 1).17 The common sense appeal of PP1 is not

17 Thomas Scanlon (1976) and Eric Mack (2014) have argued that Nozick's selfconscious antifoundationalism about rights is best understood as relying on a rejection of some unpalatable implications of utilitarianism similar to Rawls' "separateness of persons" argument. But, absent further arguments—which Nozick explicitly declines providing (1974: 9)-that line of thought is compatible with any number of conceptions of rights, or of the limits of state power. 
its only appeal, but it is our target here, given its role in Nozick's argument and in "everyday libertarianism". More importantly, as we will see in the final part of the paper, Nozick's method exemplifies the reliance on "intuition pumps" that is so widespread in contemporary Anglophone political philosophy.

To dispel some immediate doubts about our objection, two related clarifications are in order. First, we are not claiming that the coercive nature of the historical institution of private property is a problematic violation of the libertarian commitment to voluntarism and self-ownership. More generally, the issue is not that, in establishing private property rights, early states did something impermissible. We can remain neutral on that question.

Second, as anticipated in the introduction, one may worry about the genetic fallacy: how can the causal history of a belief's formation affect its truth-value? A preliminary way to answer that question is to draw on a version of what Bernard Williams calls the Critical Theory Principle: "If one comes to know that the sole reason one accepts some moral claim is that somebody's power has brought it about that one accepts it, when, further, it is in their interest that one should accept it, one will have no reason to go on accepting it." (2002: 231). As Williams recognises, this approach raises a number of further questions, e.g. "what counts as having been 'produced by' coercive power in the relevant sense" (2005: 6). Perhaps more importantly, why exactly does the justification not count? In extreme synthesis, our claim is that the concept of selfownership-which presupposes PP1—cannot be deployed to legitimise the capitalist state, 18 in much the same way that a positive referee report written by a paper's author should not be used to support that paper's publication. This is not a point about the intrinsic quality of the report; it is a procedural point about the causal history of the report making it epistemically suspect. This sort of suspicion is particularly salient when the use context is an argument with high political stakes. To be clear, it is not as if we want to rule out the philosophical relevance of any folk beliefs about social practices that have been shaped by state coercion (e.g. beliefs about equal marriage, say). We simply argue that, for reasons of epistemic caution, those beliefs should not feature in arguments about state legitimacy. The discussion of ideology in the next section will unpack this thought.

Before exploring the methodological issues that will cement our ideology critique, we should pause to consider two possible objections on the libertarian's behalf. First, the Nozickian may reply that the invisible hand scenario is meant to portray a situation in which people like us (i.e. people socialised into advanced capitalist culture), not generic humans, create a state from scratch. One may say something similar in response to critics of Hobbes' account of the state of nature: such a state may not have existed, but it would come into existence here and now if our government collapsed. The problem with this line of reply-at least for the

18 The "markets without capitalism" position (Chartier and Johnson 2011) should fare better in light of our argument, but that is beyond this paper's scope. 
Nozickian-is that it makes the theory rather circular: people socialised into capitalism would set up a capitalist social system, but that doesn't show whether being socialised into capitalism is a good thing. It doesn't show that it is a bad thing either, but we don't need to show that for our critique to go through.

The Nozickian libertarian's second objection points out that she has just imagined how a capitalist state could have arisen without rights-violations. As Nozick himself put it, "how a state would arise from that state of nature will serve our explanatory purposes, even if no actual state ever arose that way" (1974: 7). How this applies to any actual state is another matter. At the limit, a Nozickian could claim that the state she wants to justify is other than any existing states, and that the theory is not intended as a blueprint for modifying existing states.

Two rejoinders are in order here. Firstly, as Bernard Williams (1975) presciently saw, many theorists have helped themselves to Nozick's entitlement theory to defend capitalism in the actual world. Not to mention the many appropriations of versions of Nozick's entitlement theory in public political discourse as well as in academic contributions outside political philosophy - consider, for example, former chair of the US Presidency's Council of Economic Advisers Gregory Mankiw's 2013 paper 'Defending the One Percent', which features an (unacknowledged) version of Nozick's entitlement-based 'Wilt Chamberlain' argument against progressive taxation. Another example is Richard Epstein's (1985) extremely politically influential Lockean legal theory of property rights, which features in court decisions and even in US Supreme Court hearings (Ely 2006). Nozick's famous comparison between taxation and forced labour also routinely appears in political rhetoric-sometimes in even more extreme forms, as in US Senator Rand Paul's parallel between taxation and slavery (Kackzynski 2015). More generally, appeals to something like Nozick's entitlement theory often feature in electioneering as well as in the intellectual demi-monde of countless fiscally conservative think thanks.19

Secondly, Nozick acknowledges that differences between his hypothetical story and the actual world carry normative weight: More complicated are the cases where the actual history of an existing society is unjust yet some hypothetical just history could have led to the current structure (though perhaps not to the particular distribution of holdings or positions under it). If the hypothetical just history is 'close' to the actual history, whose injustices played no significant role in bringing about or maintaining the institutional structure, the actual structure will be as just as one can expect to get. (1974: 293).

19 An exemplar: "The natural inclination is to hold on to one's wages, because the natural inclination is to associate wages with oneself, as an inalienable right. If I have a right to myself I have a right to what I produce, as against all men, even if they are organized and possess political power." (Chodorov 1980). 
The distinction between the institutional structure and the distribution of entitlements under it is important, though often overlooked by critics and defenders of Nozick alike, and even by Nozick himself. The distinction puts the spotlight on what kind of entitlements a society should have: not just the question of who gets what, but also the question of what 'getting' options are available. This matters here because within Nozick's theory PP1 asserts itself at the structural level without much argument-a suspicious move for critics of ideology. But the actual history, as we have seen, is not 'close' to a hypothetical in which PP1 is assumed, since PP1 was brought (perhaps unintentionally) about through the political coercion it is now supposed to legitimise.

To bring that point into clearer focus it is worth briefly expanding on the role of PP1 in Nozick's view, where folk beliefs about private property perform two separate tasks: establishing the appeal of self-ownership, and establishing the appeal of worldownership. Setting aside the difficulties with the latter, we want to focus on why self-ownership seems to require less by way of argument to get off the ground. Why it is that the relationship between an agent and her own body should be thought of through the lens of a political-legal construct such as PP1? The answer, we suggest, has something to do with the pervasiveness of a statistcapitalist ideology.

The combination of self-ownership and world-ownership has to be compatible with a measure of negative liberty, which is why Nozick needs a theory of justice in acquisition. 20 He doesn't however explain what his theory of justice in acquisition is, only that one is required. Contrary to some libertarians' view but not Nozick's, no version of the famous Lockean proviso suffices to provide such a theory. 21 The proviso says that one may acquire parts of the world, provided that nobody is left worse off for it. But that is just to say that if appropriation is permissible, it should follow certain rules. The view has nothing to say to principled objections against private property rights over parts of the world other than persons' own bodies, which is why Nozick cites a number of well-known general defences of private property which only "...enter a Lockean theory to support the claim that appropriation of private property satisfies the intent behind the 'enough and as good left over' proviso, not as a utilitarian justification of property" (1974: 177). But, after rejecting Locke's labour-mixing theory of acquisition, Nozick does not commit to any specific alternative. He assumes that one or the other will do. Even if one is willing to grant the self-ownership assumption, this assumption that there must be a correct theory to justify the

20 Edward Feser (2005) holds the minority view that self-ownership suffices to derive world-ownership without a theory of acquisition. Our argument still applies, as self-ownership is PP1.

21 Mike Otsuka (2004), for instance, maintains that a Scanlonian interpretation of the proviso (along the lines of "acquisition is justified just in in case nobody could reasonably reject it") suffices to warrant acquisition. This move arguably conflates the conditions for specific acts of acquisition with its general permissibility. The former should be conditional on the latter. 
acquisition of private property in the external world should alarm ideology critics.

Other libertarians have tried to fill this gap in the position, e.g. by arguing that appropriation is justified by first claim, first use, discovery, first labour, object-making, integration with agents' purposes, or a 'finders keepers' principle. Much scholarly opinion, however, remains sceptical about those attempts to overcome the difficulties with Locke's labour-mixing view.22 So, libertarians who offer philosophically sophisticated defences of natural rights to private property - not to mention the many consequentialist, or instrumental defences of PP1-remain untouched by our argument. Not so for those who, like Nozick, rely on the folk appeal of PP1. For instance, Jan Narveson's (inspired by Murray Rothbard and a wider Lockean current within American political discourse) 23 maintains that all rights are property rights, i.e. he arguably grounds PP1 in the folk notion that we must have individual rights (1988: 66ff). An even clearer example is Michael Huemer. While he is commendably open to the possibility of mistaken intuitions, he explicitly states that his libertarianism rests on "common sense moral beliefs" (2013: 17). This move in turn requires a distinction between common sense morality and common sense political philosophy, with the latter cast as less reliable. But part of what our ideology critique aims to show is that the distinction between folk morality and folk political theory is not tenable, at least as long as political theory relies on moral beliefs and intuitions as its primary source of normativity.

\section{A methodological conclusion}

Let us conclude with some more general considerations on the sources of normativity in political theory. We submit that the pejoratively ideological character of libertarian entitlement-based defences of capitalism is connected to their political moralism in

Bernard Williams' (2005) sense of the term, and that the sort of genealogical critique we carried out above can help overcoming that problem, which is widespread in contemporary political philosophy.

Nozick's method is peculiar when confronted with the dominant methodology of western political thought (the last four decades excluded), insofar as it derives political recommendations from pre-political moral commitments rather than from an understanding of specifically political concepts (power, authority, and the like): "Moral philosophy sets the background for, and the boundaries of, political philosophy. What persons may and may not do to one another limits what they may do through the

22 Wenar (1998) and Widerquist (2010) provide piercingly exhaustive treatments of those views.

23 After noting its pervasiveness ("the idea that there is something distinctively friendly to libertarian thought in American intellectual and political culture is hard to distinguish from the idea that there is something especially Lockean about that culture"), Levy (2017: 23) provides a roadmap of how libertarians may move away from this Lockeanism. 
apparatus of a state, or do to establish such an apparatus" (Nozick 1974: 6). Yet this work of political theory written "in the mode of much contemporary philosophical work in epistemology or metaphysics" (ibid.: x) was to prove enormously successful from a methodological point of view, though not in terms of the views espoused in the work. In fact one may say that, if Rawls transformed the discipline, it was Nozick's rather different method that set a large part of the agenda for the debate on that transformative book and other major developments in Anglophone political philosophy. This method is characterised (inter alia) by reliance on 'intuition pumps' and other types of thought experiments, as well as other argumentative strategies designed to appeal to pre-theoretical, common sense judgments (Brownlee \& Stemplowska 2017). This approach is prevalent across political philosophy, and predominant in large subfields: one need only think of the 'equality of what' or the equality-prioritysufficiency debate with its vignettes featuring simplified disabilities and lazy surfers, or population ethics' fanciful alternative histories, of revisionist just war theory's extensive use of analogies meant to extend out intuitions about schoolyard fistfights to war between states. To name just one prominent example, in a practical guide on "How to Write Analytical Political Theory", Robert Goodin says that we should try to "get support for some proposition about which we feel less confident by showing that it follows from some other proposition in which we're more certain", and that "The way that in practice plays out in applied moral philosophy is via 'intuition pumps', examples (often contrived, artificial) about which we have a strong intuitive response." (Goodin 2017: 19). Goodin does warn intuitions may misfire; we hope to have improved our understanding of how that can happen, hopefully in ways that should caution us against equating political theory with 'applied moral philosophy'. Indeed, part of what our analysis aims to bring out is that Nozick's influential departure from the methodological canon of Western political theory was not a felicitous turn. Regardless of what one thinks of the role of intuitions in epistemology and metaphysics, there is reason to be weary of intuitions in political philosophy. Nozick's methodological shortcomings are partly due to his ethics-first and intuition-driven approach. He imagines people in the state of nature with the sorts of rights we think people have because we live under a capitalist system. He never explains why it is a good idea to ascribe such rights of self-ownership. As we have seen, he may reply that he simply wants to come up with a theory that appeals to people like us. But this undermines his methodology: it is hardly surprising that people like us have certain intuitions and beliefs about rights and the state, and to derive conclusions from those and then demand that we use those conclusions to disregard other intuitions we may have (e.g. about redistribution) is to demand too much.

Many different ideological traditions contribute to our normative outlook, and many ethics-first approaches don't have a 
clear methodology to adjudicate those clashes of intuitions (they are clashes of different bits of 'ethics as dead politics', to return to Geuss' phrase: different past victors jostling for power in the present).24 So the theory of legitimacy in Part I of Anarchy, State and Utopia is an ideological exercise that cannot be as 'explanatory' as Nozick wants it to be (Gaus 2011). The point is not just that Nozick's merely reflects but does not ground a certain libertarian normative outlook. The point is that it reflects some 'common sense' commitments whose specific role in philosophical defences of state forms does not withstand critical scrutiny. And it won't do to argue, with Huemer, that "common sense political philosophy is more controversial than common sense morality" (2013:17). His argument is, roughly, that most humans have a tendency to obey authority figures and that states and governments have a powerful influence on our cognitive capacities, so our common sense judgments about political structures are unreliable and prone to rationalization (ibid: $109 \mathrm{ff}$ ). We do not disagree with this argument insofar as it attacks common sense beliefs in authority. But we think it does not show the superiority of moral to political common sense judgments, simply because it ignores the political sources of many moral judgments that ostensibly concern purely personal matters-such as the form of ownership of one's body, to return to our main focus. Indeed the very considerations one may adduce in support of scepticism about political authority should at least lead us to examine the genealogy of our purportedly pre-political or apolitical moral beliefs. Incidentally, that is one of the lessons from the time-honoured feminist slogan, "the personal is political".

Our methodological criticism, then, ties in with an aspect of the wider realist critique of mainstream political theory: political prescriptions derived exclusively or primarily from pre-political moral commitments can turn out to be ideological in self-defeating or, at any rate, problematic ways. This is not say that all reliance on intuitions and folk beliefs is to be discarded. Rather, some such intuitions and beliefs are not suited to the tasks assigned to them. So we have shown that there is a role for genealogical ideology critique within normative political theory. But this role is different-narrower and more targeted-than the one found within traditional forms of ideology critique. Our critique targets specific uses of a concept within specific arguments. It does not seek to taint whole concepts because of their unsavoury pedigree. And when it does rule out the use of a concept in a given argument, it does so on epistemic rather than moral grounds. It is precisely the commitment to widely shared epistemic values that counsels genealogical scrutiny of concepts used to justify power relations, lest the boundary between truth and power become blurrier than it needs to be. 


\section{Authors' biographies}

Enzo Rossi (1980) is an associate professor of political theory at the University of Amsterdam and the co-editor of the European Journal of Political Theory. He has published widely on liberalism, legitimacy, ideology, and political realism.

Carlo Argenton (1983-2018) received his PhD from the London School of Economics and Political Science in 2015. He worked on liberalism, pluralism, and political realism. His first and, tragically, last academic appointment was as a postdoctoral researcher at Brown University's Political Theory Project.

\section{References}

Aytaç, U. (forth.). Bernard Williams's Realism and Epistemic Constraints. Social Theory and Practice.

Bader, R. (2010). Robert Nozick. London: Continuum.

Barry, B. (1975). Review of Anarcby, State and Utopia by Robert Nozick. Political Theory, 3(3): 331-336.

Bertram, C., (2014). Property in the Moral Life of Human Beings. Social Philosophy and Policy, 30(1-2): 404-424.

Bouchard, M. (2011). The State of the Study of the State in Anthropology. Reviews in Anthropology, 40(3): 183-209.

Brennan, J. van der Vossen, B. \& Schmidtz, D., eds (2017). The Routledge Handbook of Libertarianism. London: Routledge.

Brownlee, K. \& Z. Stemplowska (2017). Thought Experiments. In A. Blau, ed., Methods in Analytic Political Theory. Cambridge: Cambridge University Press.

Chartier, G. \& Johnson, C.W. (2011). Markets Not Capitalism: Individualist Anarchism Against Bosses, Inequality, Corporate Power, and Structural Poverty. New York: Minor Compositions.

Chodorov, F. (1980). Socialism Via Taxation. In Fugitive Essays: Selected Writings of Frank Chodorov, (Indianapolis: Liberty Fund).

Dagan, H. (2011). Property: V alues and Institutions. Oxford: Oxford University Press.

Deakin, S. et al. (2016). Legal Institutionalism: Capitalism and the Constitutive Role of Law. Journal of Comparative Economics, 45: 188-200.

Deagan, K., \& Cruxent, J.M. (2002). Columbus's Outpost among the Tainos. Princeton, NJ: Princeton University Press.

Earle, T. (2000). Archaeology, Property, and Prehistory. Annual Review of Anthropology 29: 39-60.

Earle, T. (2017). Property in Prehistory. In M. Graziadei \& L. Smith, eds, Comparative Property Law. Cheltenham: Edward Elgar.

Ely, J.W. (2006). Impact of Richard A. Epstein. William \& Mary Bill of Rights Journal, 15(2): 421-8.

Epstein, R.A. (1985). Takings. Cambridge, MA: Harvard University Press.

Farringdon, J.D., (2005). De-Development in Eastern Kyrgyzstan and Persistence of Semi-nomadic Livestock Herding. Nomadic Peoples, 9.1-2, pp. 171-197.

Feser, E. (2005). There is No Such Thing as an Unjust Initial Acquisition. Social Philosophy and Policy, 22(1): 56-80.

Fried, M.H. 1967. The Evolution of Political Society: An Essay in Political Anthropology. New York: Random House.

Gailey, C.W. (1985). The State of the State in Anthropology. Dialectical Anthropology, (9)1: 65-89. 
Gaus, G. (2011). Explanation, Justification, and Emergent Properties: An Essay on Nozickian Metatheory. In The Cambridge Companion to Nozick's 'Anarchy, State, and Utopia', edited by Ralf M. Bader and John Meadowcroft. Cambridge: Cambridge University Press.

Geuss, R. (2008). Philosophy and Real Politics. Princeton, NJ: Oxford University Press.

Gibson, D.B. (2008). Chiefdoms and the Emergence of Private Property in Land. Journal of Anthropological Archaeology, 27(1): 46-62.

Gilman, A. (1998). Reconstructing Property Systems from Archaeological Evidence. In RC Hunt \& A. Gilman, eds, Property in Economic Context. Lanham, MD: University Press of America.

Goodin, R.E. (2017). How to Write Analytical Political Theory. In A. Blau, ed., Methods in Analytical Political Theory. Cambridge: Cambridge University Press.

Granovetter, M. (1985). Economic Action and Social Structure: The Problem of Embeddedness. American Journal of Sociology, 91(3): 481-510

Hall, E. (2015). How To Do Realistic Political Theory (and Why You Might Want To). European Journal of Political Theory, DOI: $10.1177 / 1474885115577820$.

Hall, P. \& D. Soskice, eds, 2001. Varieties of Capitalism. Oxford: Oxford University Press.

Haslanger, S. (2012). Resisting Reality. Oxford: Oxford University Press.

Hodgson, G.M. (2016). Conceptualizing Capitalism. Competition \& Change, 20(1): 37-52.

Huemer, M. (2013). The Problem of Political Authority. New York: Macmillan.

Johnsen, D. (1986). The Formation and Protection of Property Rights among the Southern Kwakiutl Indians. The Journal of Legal Studies, 15 (1): 41-67.

Jost, J.T. \& Hunyady, O., (2005). Antecedents and Consequences of SystemJustifying Ideologies. Current Directions in Psychological Science, 14(5): 260265.

Kackzynski, Andrew (2015). Rand Paul Philosophizes on Tax Rates: "If We Tax You At 50\%, You Are Half Slave, Half Free". BurzFeed Nens, July 6.

Kalit, K. and E. Young (1997). Common Property Conflict and Resolution: Aboriginal Australia and Papua New Guinea, in The Governance of Common Property in the Pacific Region, ed. Peter Larmour, Canberra: National Centre for Development Studies and Resource Management in Asia-Pacific.

Lee, R.B. and R. Daly, eds (1999). The Cambridge Encyclopaedia of Hunters and Gatherers. Cambridge: Cambridge University Press.

Levy, J.T. (2017). Contra Politanism. European Journal of Political Theory, OnlineFirst, URL: bttps://doi.org/10.1177/1474885117718371

----(2017). Toward a Non-Lockean Libertarianism. In J. Brennan, B. van der Vossen \& D. Schmidtz, eds, The Routledge Handbook of Libertarianism. New York: Routledge.

Mack, E. (2010). The Natural Right of Property. Social Philosophy \& Policy, 27(1): 53-78.

Mack, E. (2014). Robert Nozick's Political Philosophy", The Stanford Encyclopedia of Philosophy, Edward N. Zalta, ed., URL = <http://plato.stanford.edu/archives/sum2015/entries/nozickpolitical/>

Mankiw, N.G. (2013). Defending the One Percent. Journal of Economic Perspectives, 27(3): 21-34.

McKean, M.A. and E. Ostrom (1995). Common property regimes in the forest: just a relic from the past? Unasylva, 46(180): 3-15.

Meiskins Wood, E. (2002). The Origin of Capitalism: A Longer View. London: Verso.

Merrill, T.W. (1998). Property and the Right to Exclude. Nebraska Law Review, 77: 730-55. 
Murphy, L.D. \& Nagel, T. (2002). The Myth of Ownership. Oxford: Oxford University Press.

Nagel, \&. (1975). Libertarianism Without Foundations. The Yale Law Journal, 85(1): 136-149.

Narveson, J. (1988). The Libertarian Idea. Philadelphia, PA: Temple University Press.

Nozick, R. (1974). Anarchy, State and Utopia. New York: Random House.

O'Neill, O. (1987). Abstraction, Idealization and Ideology in Ethics. Royal Institute of Philosophy Lecture Series, 22: 55-69.

Oldenburg, V.T. (2002). Dowry Murder: The Imperial Origins of a Cultural Crime. Oxford: Oxford University Press.

Olsaretti, S., (2004). Liberty, Desert and the Market, Cambridge: Cambridge University Press.

Otsuka, M. (2004). Libertarianism Without Inequality. Oxford: Oxford University Press.

Parker, L.S. (1989). Native American Estate. Honolulu: University of Hawaii Press.

Penner, J.E. (1997). The Idea of Property in Law. Oxford: Oxford University Press.

Perelman, M. (2000). The Invention of Capitalism, Durham, NC: Duke University Press.

Pateman, C., (2002). Self-Ownership and Property in the Person: Democratization and a Tale of Two Concepts. Journal of Political Philosophy, 10(1): 20-53.

Piketty, T. (2014). Capital in the Twenty-First Century. Cambridge, MA: Harvard University Press.

Pierson, J. (2013). Just Property: A History in the Latin West. Oxford: Oxford University Press.

Porter, A. (2012). Mobile Pastoralism and the Formation of Near Eastern Civilizations. Cambridge: Cambridge University Press.

Rol, M. (2008). Idealization, Abstraction, and the Policy Relevance of Economic Theories. Journal of Economic Methodology, Volume 15, Issue 1.

Rossi, E. \& Sleat, M. (2014). Realism in Normative Political Theory. Philosophy Compass, 9(10): 689-701.

----(2016). Facts, Principles, and (Real) Politics. Ethical Theory and Moral

Practice, 19(2): 505-520.

----(2019). Being Realistic and Demanding the Impossible. Constellations, URL: $\quad$ https://onlinelibrary.wiley.com/doi/full/10.1111/14678675.12446

Sahlins, M. (1974). Stone Age Economics. London: Tavistock.

Scanlon, T. (1976). Nozick on Rights, Liberty, and Property. Philosophy \& Public Affairs, 6(1): 3-25.

Scott, J.C. (1998). Seeing Like a State. New Haven, CT: Yale University Press.

Stanley, J. (2015). How Propaganda Works. Princeton, NJ: Princeton University Press.

Trigger, B.G. (2003). Understanding Early Civilizations: A Comparative Study. Cambridge: Cambridge University Press

Waldron, J. (1988). The Right to Private Property. Oxford: Clarendon Press.

Wenar, L. (1998). 1998. Original acquisition of private property, Mind, 107, pp.799-819

Widerquist, K. \& McCall, G. (2017). Prehistoric Myths in Modern Political Philosophy. Edinburgh: Edinburgh University Press.

Widerquist, K., \& McCall, G. (2015). Myths About the State of Nature and the Reality of Stateless Societies. Analyse \& Kritik, (1-2 2015): 233-257.

Widerquist, K. (2010). Lockean Theories of Property: Justifications for Unilateral Appropriation. Public Reason, 2(1), pp.3-26.

Wildlok, T. (2005). Introduction, in T. Widlok \& W.G. Tadesse, eds, Property and Equality, Vol. I. Oxfrord: Berghahn. 
Williams, B., (1975). Review of Anarchy State \& Utopia, in Essays and Reviews: 1959-2002, Princeton, NJ: Princeton University Press, 2015.

Williams, B. (2005). In the Beginning Was the Deed: Realism and Moralism in Political Argument. Princeton, NJ: Princeton University Press.

Williams, B. (2002). Truth and Truthfulness. Princeton, NJ: Princeton University Press.

Wood, A. (2004). Karl Marx. London: Routledge.

Woodcock, G. (1962). Anarchism: A History of Libertarian Ideas and Movements. New York: Meridian Books. 